CHAPTER 49

\title{
RESEARCHES ON STEEL-PIPE BREAKWATER
}

\author{
S. Nagai \\ Professor of Hydraulic Engineering, \\ Department of Civil Engineering, \\ Faculty of Engineering, \\ Osaka City University, \\ Osaka, Japan.
}

\section{INTRODUCTION}

As a new type of vertical-wall breakwater built in soft ground a breakwater, composed of a single row of large steel pipes with diameters of some 1.5 to 3.0 meters driven into a sea bottom, has been proposed for the water areas where are not directly exposed to a great ocean. Experiments for the fundamental study were conducted in the medium wave channel of the hydraulic laboratory in Osaka City University, and model experiments were performed for practical design of the steel pipe breakwater planned to build in the Port of Osaka at a $1 / 10$ scale in the large wave tank in the Field Hydraulic Laboratory.

\section{PART I, FUNDAMENTAI STUDY}

\section{EXPERIMENTAL EQUIFMENT AND PROCEDURES}

The experiments were performed in the medium wave channel, $25 \mathrm{~m}$ long, $2.0 \mathrm{~m}$ wide and $1.2 \mathrm{~m}$ deep, and the model breakwater was composed of a single row of steel pipes with a diameter of $10 \mathrm{~cm}$ which were fixed perpendicular to the bottom of the wave channel in close contact with each other, as seen in Fig. 1. Waves were generated by a flutter-type wave generating machine located at the counter-side to the model breakwater in the channel, and the periods, heights and lengths of the waves used in the experiments were $\mathrm{Tm}=1.23 \mathrm{sec}$ to $1.8 \mathrm{sec}, \quad \mathrm{Hm}=13 \mathrm{~cm}$ to $20 \mathrm{~cm}$ and $\mathrm{Im}=200 \mathrm{~cm}$ to $300 \mathrm{~cm}$ in the water depths $\mathrm{hm}=40 \mathrm{~cm}$ to $60 \mathrm{~cm}$. If the modelto-prototype scale is taken as $1 / 15$, the diameter of the pipe, the characteristics of the waves and the water depths used in the experiments would be equivalent in prototype to $D p=1.5 \mathrm{~m}$, $T p=4.7 \mathrm{sec}$ to $8.0 \mathrm{sec}, \mathrm{Hp}=2 \mathrm{~m}$ to $3 \mathrm{~m}, \mathrm{Lp}=30 \mathrm{~cm}$ to $60 \mathrm{~cm}, \mathrm{hp}=6 \mathrm{~m}$ to $9 \mathrm{~m}$ respectively.

The pressures of the waves exerted on the steel-pipe breakwater were measured at the top-face and side of the steel pipe, as shown in Fig. 2, by the simultaneous use of six pressure gauges of strain-guage type, and the wave pressures exerted on a breakwater with a plain vertical wall were also measured in the 
same characteristics of waves and water depths as those used in the tests of the steel-pipe breakwater for the comparison between ther. The resultant of the wave pressures exerted on one steel pipe was measured by the measurement of moments at two points on the pipe (Tigs. 21, 22) in order to check the resultant of the wave pressures obtalned by the vertical distribution curves of the pressures recoraed on the six pressure gauges.

The heights of the waves were recorded just in front of the breakwater and at distances of $5.5 \mathrm{~m}$ and $7.0 \mathrm{~m}$ offshore from the breakwater by use of three wave recorders of strain-gauge type.

\section{WAVE, PRESSURES EXEPTED ON THE STEEL-I IFE BREAKUATER}

IAVE PRESSURES ON THE TOP-FACE OF THE STEJL-TIFE

\section{a) BREAKNATER WITHOUT A RUDILH; MOUND}

The Intensutıes of wave pressures and thelr vertical distributions on the top face of the circular steel pipe are lllustrated in Fıgs. 3a, 4a, 5a, 6a, 7a and $8 a$, in comparison with those of the breakwater with a plain vertical wall. In these fieures Fe denotes the resultant of the wave pressures measured on the top face of the pipe, Is is the resultant wave pressure calculated by Salnflou's simplified method which is obtalned by

$$
P_{S}=\frac{1}{2} N_{0}\left(H+\delta_{0}+h\right)\left(h+\frac{H}{\cosh m h}\right)
$$

where $\delta_{0}=\frac{\pi \mathrm{H}^{2}}{\mathrm{~L}} \operatorname{coth} \mathrm{mh}, \quad \mathrm{m}=\frac{2 \pi}{\mathrm{L},}$ and wo defines the unit weight of water.

$F_{c}$ ls the resultant pressure calculated by the following equation derived from the small amplitude wave theory

$$
\begin{aligned}
P_{C}=\frac{1}{2} & W_{0}\left(h^{2}-H^{2}\right)+W_{0} H\left\{h+H+\frac{\sinh (h+H)}{m \cosh m}\right. \\
& \left.-(h+H) \frac{\cosh m(h+H)}{\cosh m h}\right\},
\end{aligned}
$$

and PA is the resultant pressure calculated by the equation of maximum simultaneous pressure proposed by the author for standing waves in shallow water, $h / L \leqq 0.35$,

$$
P_{A}=\frac{1}{2} N_{0}\left(h^{2}+H^{2}\right)+w_{0} \frac{H}{m} \tanh m h
$$

Figs. 3b, 4b, 5b, 6b, 7b and $8 \mathrm{~b}$ show the behaviors of the waves in front of the vertical walls in Flgs. 3a, 4a, 5a, 6a, $7 a$ and 8 a respectively.

As seen in Figs. zb to $8 \mathrm{~b}$, the crests of the waves slightly break on the vertical wall of steel plpes, causine small increase in the Intensities of pressure around the still water surface. 
Accordingly the resultants of wave pressures exerted on the steel-pipe breakwater were 3 to 24 per cent larger than those on the plain vertical wall. The vertical distributions of the pressures measured and the resultants of those pressures are in comparatively good agreement with those calculated by the equation (A), being the ratioes between $\mathrm{Pe}$ and $\mathrm{PA}_{\mathrm{A}}, \mathrm{Pe} / \mathrm{P}_{\mathrm{A}}=0.84$ to 0.88 for the plain vertical wall, and $P_{e} / P_{A}=0.94$ to 1.00 for the steel-pipe breakwater. Thls result indicates that the concentration of wave energy into the concave part between the two adjacent circular pipes is not considerable in the steel-pipe breakwater usec in these experiments whlle it was much larger in vertical-wall breakwaters which were constructed with larger cells $10 \mathrm{~m}$ to $15 \mathrm{~m}$ in diameter. The characteristics of the waves tested and the resultants of the wave pressures which were measured and calculated are listed in Table 1.

\section{b) BREAKTATER WTTH A RUBBLE MOUND}

Although a rubble mound will be considered to be built at the harbor-and sea-sides of a steel-pipe breakwater in order to reduce the deflections of the steel pipe at the sea-bottom, it was clearly proven by the experiments that the construction of the base-rubble mound made waves break and increased the pressures of the waves exerted on the steel pipes, creating sometimes shock pressures of comparatively large intensity. The effect of the rubble mound on the wave rressures exerted on the steel-pipe breakwaters as well as on the plain vertical walls are shown in Figs. $9 \sim 14$, and Figs. 15 20 show the behaviors of the waves in front of the steel-pipe breakwaters in the cases of Flgs. $9 \sim 14$ respectively. The experimental data are listed in Table 2.

The resultants of the wave pressures exerted on the steelpipe breakwater with a rubble mound were also 2 to 36 per cent larger than those on the plain vertical wall with a rubble mound, and as the water depth on the rubble mound, hl, decreases, the pressures of waves increase, following shock pressures of comparatively large intensity, the vertical distriputions of which are sImI] ar to the A-type of high shock pressures? when $h_{1} / H$ are 1.3 to 1.4 or little less.

\section{WAVE PRESSURES ON THE SIDES OF THE STEEL-PIPE}

The pressures of waves exerted on the sides of the steel pipe were qeasured at the points with an angle 47 degrees to the direction of the oncoming wave, as shown in Fig. 2, in the steelpipe breakwaters wathout and with a rubble mound. The data of these experiments are summarized in Tables 3 and 4.

(1) Nagai, S., "Shock Pressures Exerted by Breaking Waves on Breakwaters", Froc. A.S.C.E., Waterways and Harbors Division, Vol. 86, June 1960. 
From Tables 3 and 4 it is noted that the wave pressures exerted on the side of the pipe are a little larcer in many cases of the experiments than those on the top face of the pipe, while the former show a little smaller values than the latter in the three cases of the experiments. Hccordingly it may be said that there is seen no distinguished concentration of wave energy into the concave part between the two adjacent curcular pipes in the vertical breakwater composed of a single row of steel pipes with a diameter of $1.5 \mathrm{~m}$ in the wave conditions used in these experiments.

\section{WAVE FRESSURES WXERTED ON ONE STEEL EIFE OF} THE' STEEL-FIPE RREAKTATER

A steel pipe with the same diameter of $10 \mathrm{~cm}$ as that of the steel pipes of the breakwater was suspended from a fixed point located over the wave channel at the middle part of the breakwater, as seen in Fiss. 21 and 22. Moments exerted by the oncoming waves were measured at the points of $G_{1}$ and $G_{2}$ in Fig.22. The resultant of the pressures, $P_{x}$, on the steel pIpe and the point of application of the resultant pressure, $l x$, were calculated by

$$
P_{x}=\frac{M_{1}-N_{2}}{l} \text { and } \quad l_{x}=\frac{M_{2}}{M_{1}-M_{2}} l
$$

$P_{x}$ were compared with the resultant pressures, Pme, obtained by the vertical distribution curves of pressures measured on the top face of the steel pipe and those calculated by the equation (A), PmA. Those data are listed in Table 5 .

From Table 5 it is noted that $P x$ are 13 to 23 per cent larger than Pme. In view of the result that the resultant pressures on the sides of the pipe are a IIttle larger, up to 14 per cent, than those on the top face of the plpe, the values of $P_{x}$ may be said probably correct.

\section{EART II. MODEL STUDY OF THE STYEL-PIPE BREALVATER} IN THE IORT OF ODAKA

\section{MAIN E URIOSES OF TEE UXPERIN.SNT}

The steel-pipe brealwater composed of a single row of 60 steel pipes with a diameter of 2 meters was declded to be built at the entrance of the North harbor (entrance width $=160 \mathrm{~m}$ ) in the Port of Osaka when our fundamental study had been performed, and the model experiments were conducted in the large wave tank for the steel-pipe breakwater which was under design to be built in the Fort of usaka.

The main purposes of this model experiment were: (1) Measurements of the wave pressures and their vertical distributzons on the steel pipe as well as of the sheltering effect of 
the breakwater when the steel pipes are driven at some 5 to $10 \mathrm{~cm}$ space between the adjacent pipes; (2) finding the way of reconstruction after destructions of part of the breakwater due to the collision of drifting ships during typhoons.

\section{EXPERTMENTAL EOUIPMENT AND PROCEDURES}

The model experiments were performed at a 1/10-model-toprototype scale in the large wave tank, $60 \mathrm{~m}$ long, $10 \mathrm{~m}$ wide and 2.5m deep. The model steel pipes with a diameter of $20 \mathrm{~cm}$ were fixed perpendicular to the bottom of the tank at an constant space of one $\mathrm{cm}$ between the adjacent pipes (Fig. 24), and the tops of the pipes were fixed in some experiments and free in other experiments in which the deflections of the top were measured (Fig. 26).

The heights of the oncoming waves were measured by two waverecorders located at $10 \mathrm{~m}$ and $13 \mathrm{~m}$ seaward from the breakwater and the heights of the waves transmitted to harbor-side through the spaces between the pipes were measured at $3 \mathrm{~m}$ and $6 \mathrm{~m}$ distances from the breakwater (Fig. 23), in two cases when the one-cm-spaces between the pipes ran entirely from the top to the bottom of the pipe and the spaces above the low water level were shut of $f$ waves passing into the harbor basin by iron plates welded to the both sides of the pipes. (Fig. 27)

The characteristics of waves used in the experiments were $\mathrm{Tm}($ period) $=1.58 \mathrm{sec}$ to $2.20 \mathrm{sec}, \mathrm{Tp}$ (period in prototype) $=5.0$ sec to 7.0 sec, and Hm (height) $=17.7 \mathrm{~cm} \mathrm{to} 30 \mathrm{~cm}$, Hp (height in prototype) $=1.77 \mathrm{~m}$ to $3.0 \mathrm{~m}$. The kinds of the experiments performed are listed in Table 6 .

\section{EXPERIMENTAL RESULTS AND SOME CCNAIDERATICNS}

\section{FIXED TOPS CF STEEL TIPES WITH SHELTER-FLATES}

The experimental results are summarized in Table $7(a)$ when the tops of the steel pipes were fixed and all the spaces between the adjacent pipes were shut up with shelter-plates from the low water level to the top of the pipe, the heights of which vere changed $17 \mathrm{~cm}$ and $36 \mathrm{~cm}$ above the low water level, that is, D.L. $+5.0 \mathrm{~m}$ and $+7.0 \mathrm{~m}$ above the datum low water level in prototype.

The intensities of pressures exerted on the top face and side of the plpe as well as tneir vertical distributions in Runs No. 1 and 6 are shown in Fig. 28 , and those in Runs No. 5 and 10 shown In Fig. 29. The behaviors of the waves around the breakwater are shown in Figs. 30(a), 30(b), 31(a) and 31(b).

The ratioes of the resultant pressures between on the top face and side of the pipe are 0.99 to 1.16 , and these ratioes are nearly same as those of 0.94 to 1.14 obtained in the fundamental experiments in which steel pipes were stood close together. 
When the tops of the steel pipes were deflected up to $2 \mathrm{~cm}$ at the tops, the pressures exerted on the pipes decreased slightly on the top face of the pipe but those on the side increased slightly, and the ratioes between the resultant pressures on the top face of the pipe and calculated by the equation(A), $P_{A}$, were 0.63 to 1.08 , as well as the ratioes of the resultant pressures between on the side and top face of the pipe were 1.19 to 1.89. These experimental data are listed in Table $7(\mathrm{~b})$.

\section{FIXED TOPS OF STEEL PIPES WITHOUT SHELTER-PLATES}

When the tops of the steel pipes were fixed and all the shelter-plates were taken of to make waves freely transmit into the harbor basin through the one-cm spaces between the adjacent pipes, the pressures on the top of the pipe decreased some 10 per cent compared with those in the breakwater with the shelter-plates, but the pressures on the side of the pape did not decrease. The man reason 18 considered due to the concentration of wave energy into the spaces. The experimental results are listed in Table $7(\mathrm{c})$. The pressure distribution curves on the top and side of the pipe in Runs No.3 and 6 in Table $7(\mathrm{c})$ are depicted in FIg. 32, and the behaviors of waves in those runs are shown in Figs. $33(a)$ and (b) respectively.

\section{TRANSMISSTON OF WAVES THRO' THE SPACES BETWEEN THE PIFES}

If the diameter of the steel pipe and the space between the adjacent pipes are denoted by $\mathrm{D}$ and $\mathrm{d}$, ratio, $\mathrm{H} T / \mathrm{HI}$, between the height of the wave transmitted through the spaces, $H_{T}$ and that of the incoming wave, $\mathrm{H}_{l}$, is obtained by

$$
\frac{H_{T}}{H_{l}}=\sqrt{\frac{d}{D+d}}
$$

Taking $y$ the vertical distance to which the shelter-plate extends below the still water surface, the ratio, $\mathrm{H}_{\mathrm{T}} / \mathrm{H}_{\mathrm{I}}$, of height of wave, $H_{T}^{\prime}$ ' transmitted between the bottom and the depth $y$ below the still water level, to the ${ }_{2}$ igcoming wave height $H_{1}$ is obtained for waves of small amplitude $\left(\frac{1}{2}\right)$

$$
\frac{H_{f}^{\prime}}{H_{1}}=\sqrt{\frac{d}{D+d}} \sqrt{\frac{\frac{4 \pi(y+h) / L}{\sinh (4 \pi h / L)}+\frac{\sinh 4 \pi(y+h) / L}{\sinh (4 \pi h / L)}}{1+\frac{4 \pi h / L}{\sinh (4 \pi h / L)}}}
$$

(2) Wiegel, Robert L., "Transmission of Waves Past A Rigid Vertical Thin Barrier", Proc. A.S.C.E., WWI, March, 1960. 
where $h$ is the water depth, and $L$ denotes the wave length.

The results of comparisons between the experimental values of $\mathrm{H}_{\mathrm{T}} / \mathrm{H}_{\mathrm{I}}$ and $\mathrm{H}_{\mathrm{T}} / \mathrm{H}_{I}$, theoretical values calculated by the two equations described above are shown in Tables $7(a)$, and. (c). The comparisons show:

(1) Then there was no overtopping of waves in the steel-pipe braakwater with the shelter-plates, the experimental values of $\mathrm{H} \mathrm{T}_{\mathrm{T}} / \mathrm{H}_{\mathrm{I}}$ are generally in good agreement with the calculated values. (Table $7(\mathrm{a})$ ).

(2) When no overtopping of waves was seen in the steel-pipe breakwater without the shelter plates, the experimental values of $\mathrm{H}_{T} / \mathrm{H}_{\mathrm{I}}$ are 6 to 11 per cent larger than the calculated ones (Table $7(\mathrm{c}))$. This is due to the concentration of waves into the one-cm spaces between the adjacent circular pipes.

(3) When waves overtop over the top of the breakwater, the values of $\mathrm{H}_{T} / \mathrm{H}_{\mathrm{t}}$ and $\mathrm{H}_{T} / \mathrm{H}_{1}$ increase up to some 20 per cent.

(4) When the top of the breakwater without the shelter-plates oscillated with a maximum amplitude of $7 \mathrm{~cm}$, the experimental values of $\mathrm{H}_{T} / \mathrm{H}_{1}$ were 26 to 37 per cent, which were little larger than those of the breakwater with fixed top.

\section{EXPERIMENTS FOR RECONSTRUCTION}

There was little anxiety about severe damages of the steelpipe breakwater due to waves as the design wave was so small that $\mathrm{Hp}=2$ to $3 \mathrm{~m}, \mathrm{Tp}=5$ to $7 \mathrm{sec}$. But a great possibility was considered to serious damages due to the collision of drifting ships during typhoons. As a way of reconstuction of part of the breakwater after the destructions, it was proposed to move the destructed part of the breakwater by some $2 \mathrm{~m}$ seaward from the site of the breakwater and drive again steel pipes $2 \mathrm{~m}$ in diameter into the sea-bottom there.

Several experiments in such situation of the breakwater were conducted to know any changes in wave pressures exerted on the steel pipes and waves transmitted into the harbor basin. It was proven from the experiments that there would be no remarkable increases in the wave pressures and the wave heights transmitted into the harbor basin. Figs. 34 and 35 show experiments concerned with the reconstructed part of the breakwater.

\section{CONSTRUCTION OF THE BREAKWATER}

The construction of the breakwater, which was composed of 60 steel pipes $2 \mathrm{~m}$ in diameter, was started in $\mathrm{July}, 1965$ in the Port of Osaka and completed at the end of May, 1966. The spaces between the adjacent steel pipes were some $5 \mathrm{~cm}$ in average. Fig. 36 shows the steel-pipe breakwater in near completion, and Fig. 37 the breakwater undergoing horizontal load tests in May, 1966. Figs. 38 and 39 shows the breakwater after the completion. 


\section{ACKNONLEDGMENTS}

The writer wishes to express his appreciation to three assistants, $\mathrm{Mr} . \mathrm{S}$. Kubo, K. Oda, and K. Tokikawa, in the writer's laboratory for performing the laboratory experiments and for preparing the illustrations, and to Miss. Y. Ueno for typing the orıginal manuscript. 


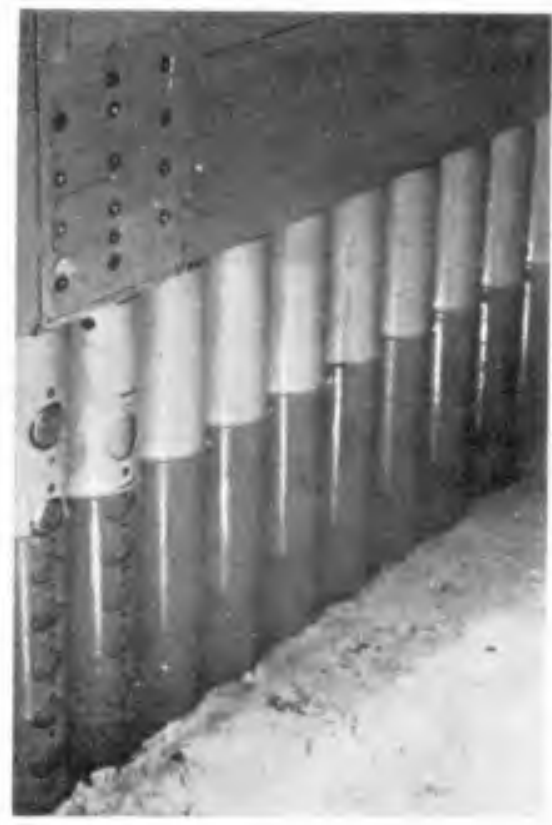

Fig. 1. Model of the steelpipe breakwater.

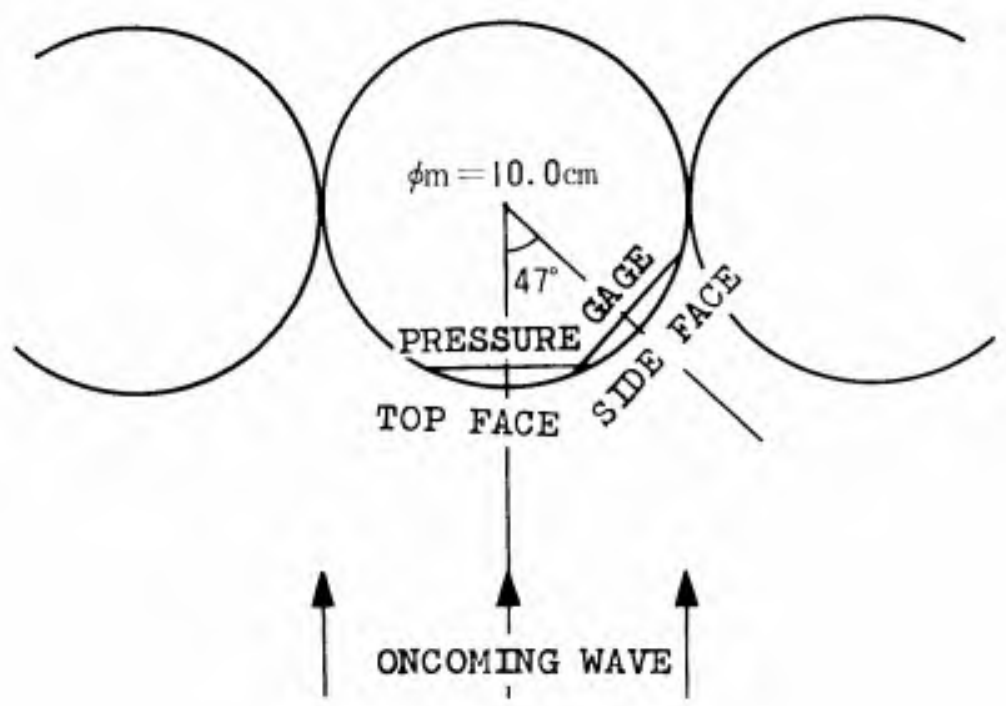

Fig. 2. Plan of the steel-pipe breakwater and locations of the pressure-gauges. 


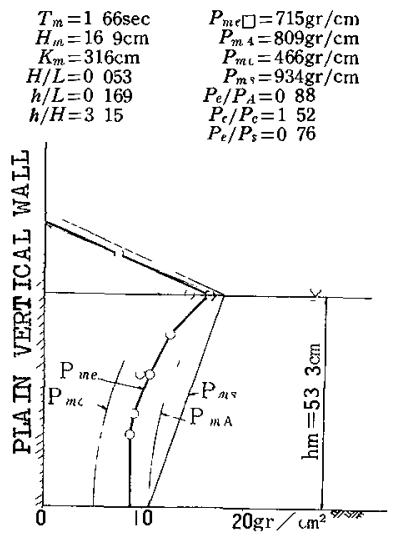

Fig. 3(a).

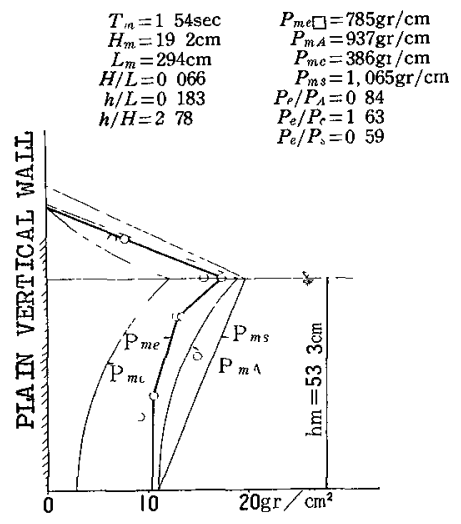

Fig. 5(a).

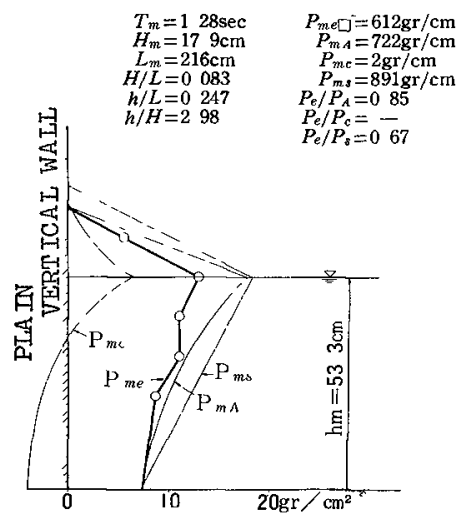

Fig. 7(a).

Figs. 3(a) - 7(a). Vertical distributions of wave pressures on the plain vertical wall.

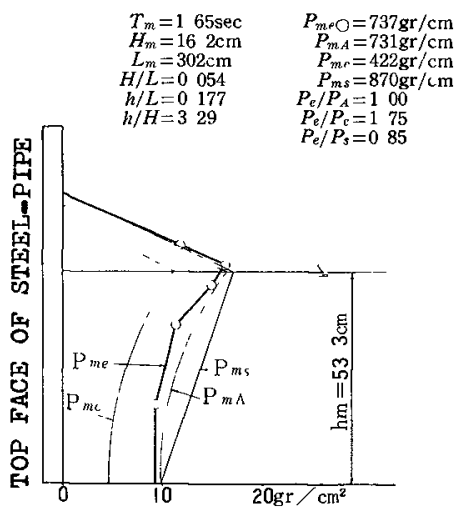

Fig. 4(a).

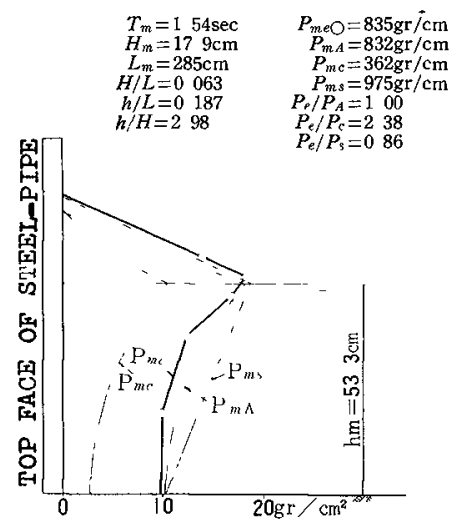

Fig. 6(a).

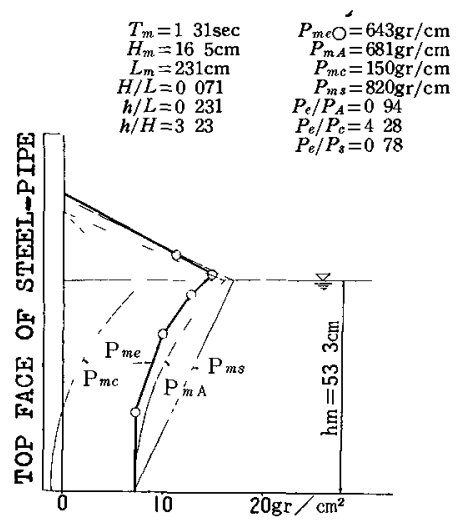

Fig. 8(a).

Figs. 4(a) -8 (a). Vertical distributions of wave pressures on the steel-pipe breakwater. 


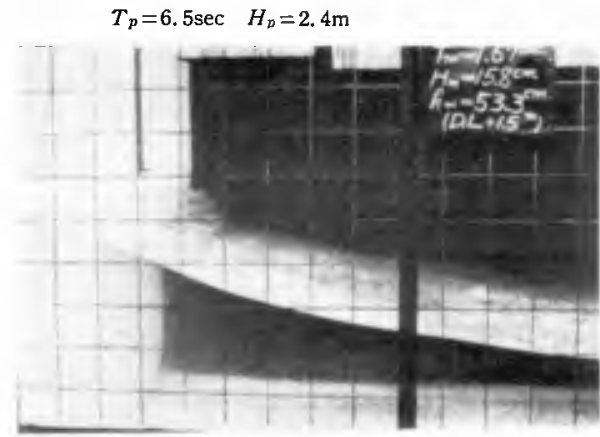

Fig. 3(b).

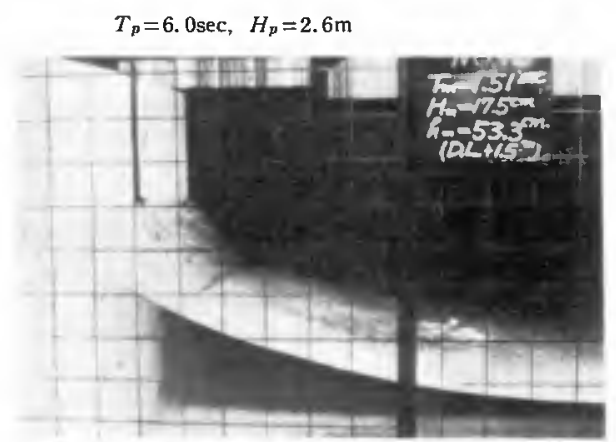

Fig. 5(b).

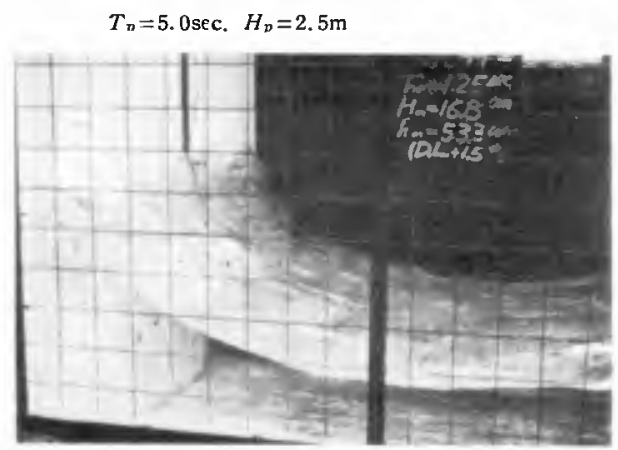

Fig. 7(b).

Figs. 3(b) $-7(b)$. Behavior of wave in front of the plain vertical wall.

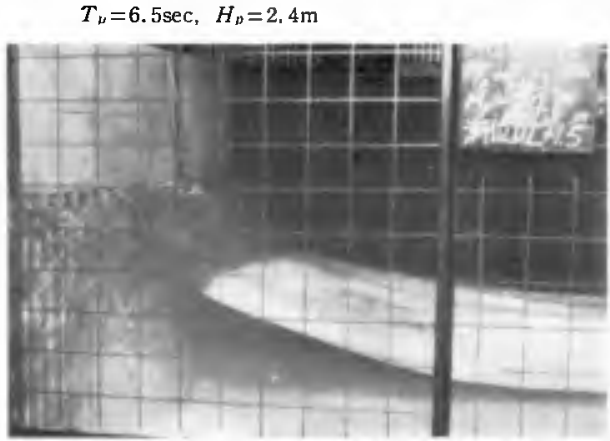

Fig. 4(b).

$T_{p}=6.0$ sec, $H_{p}=2.6 \mathrm{~m}$

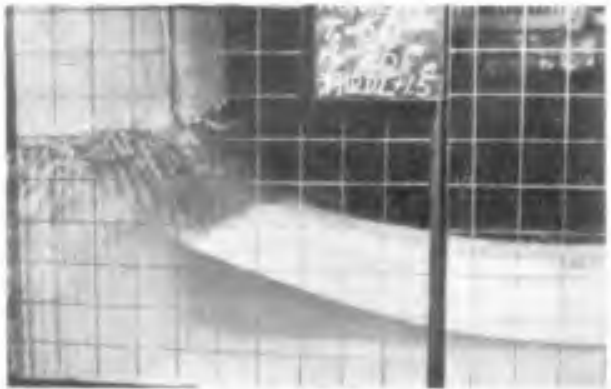

Fig. 6(b).

$T_{p}=5.0 \mathrm{sec}, \quad H_{p}=2.5 \mathrm{~m}$

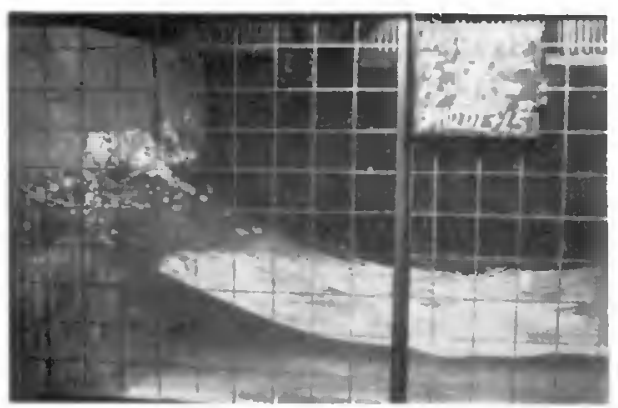

Fig. $8(b)$.

Figs. 4(b) $-8(\mathrm{~b})$. Behavior of wave in front of the steel-pipe breakwater. 


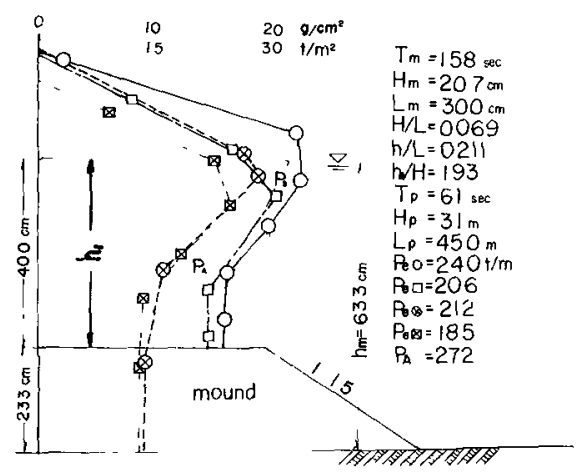

Fig. 9.

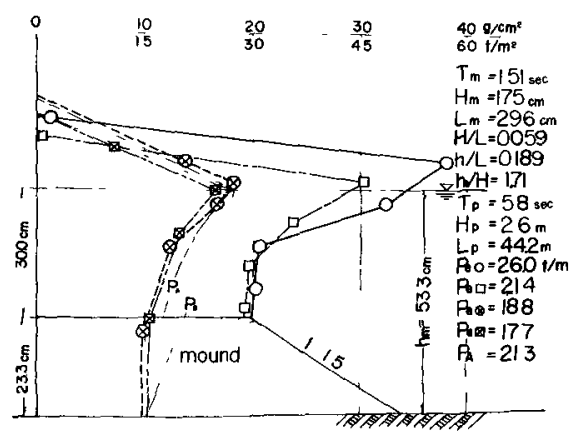

Fig. 11.

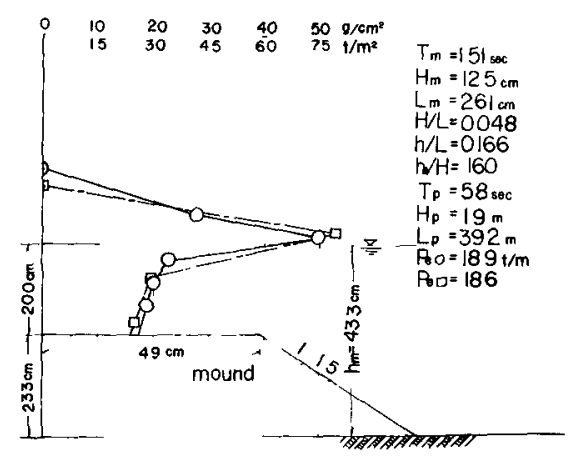

Fig. 13.

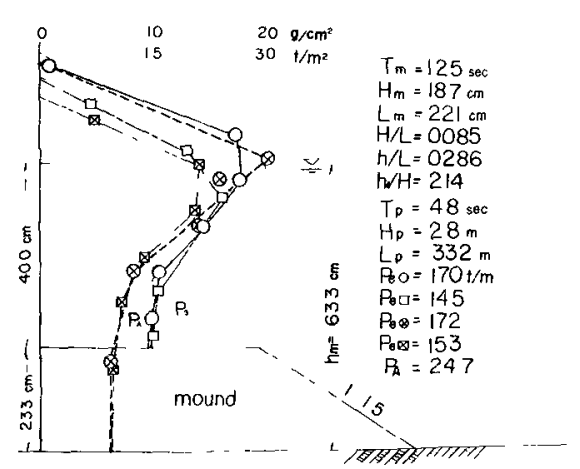

Fig. 10.

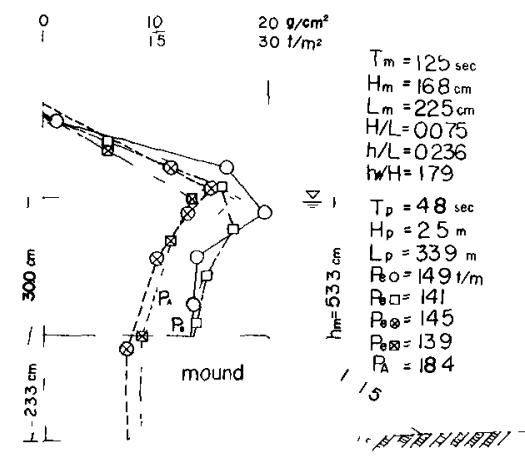

Fig. 12.

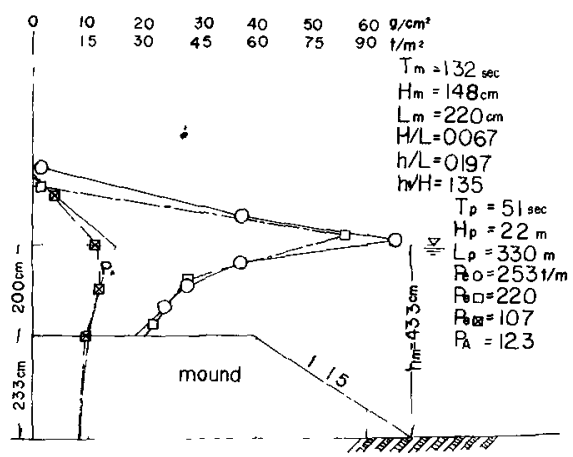

Fig. 14.

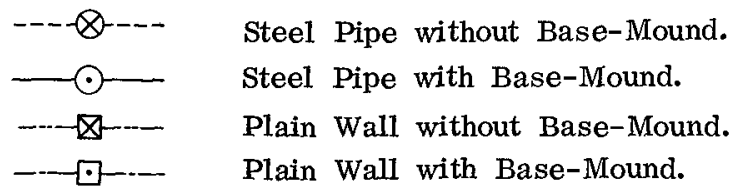

Fig. 9 - 14. Comparisons of the pressures on the steel-pipe breakwaters with and without a base-rubble mound. 


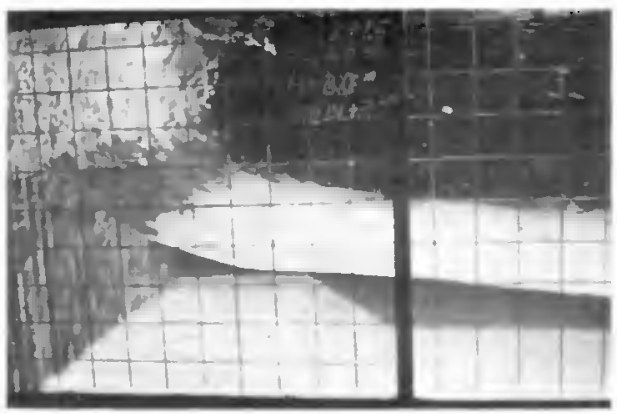

Fig. 15.

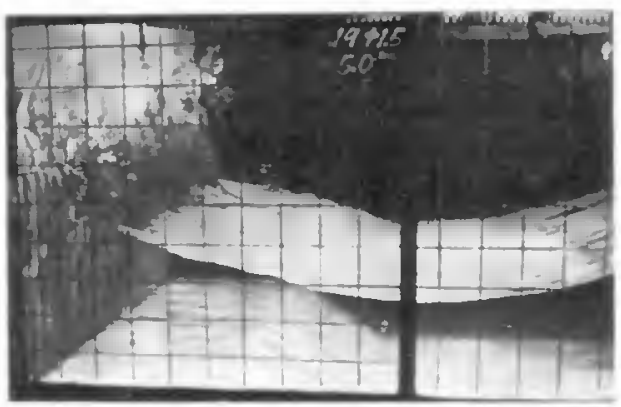

Fig. 16.

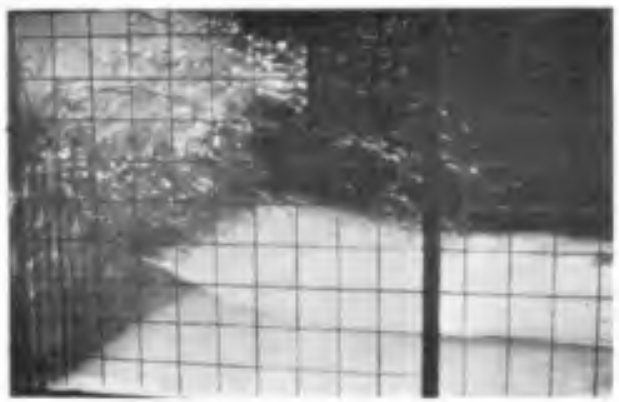

Fig. 17.

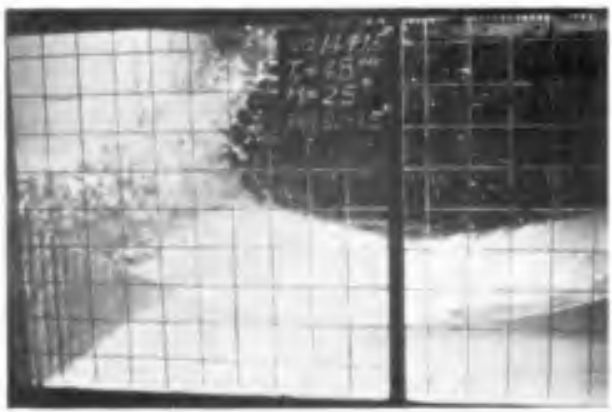

Fig. 18.

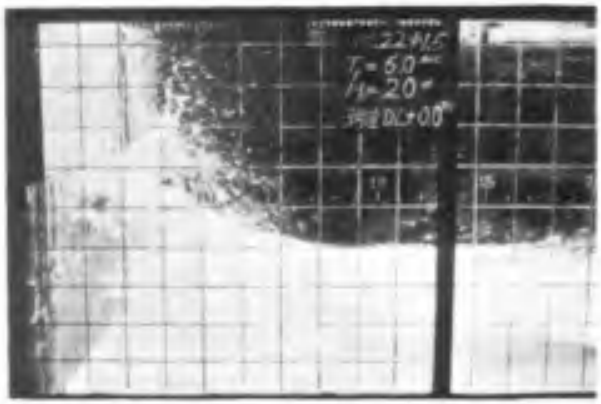

Fig. 19.

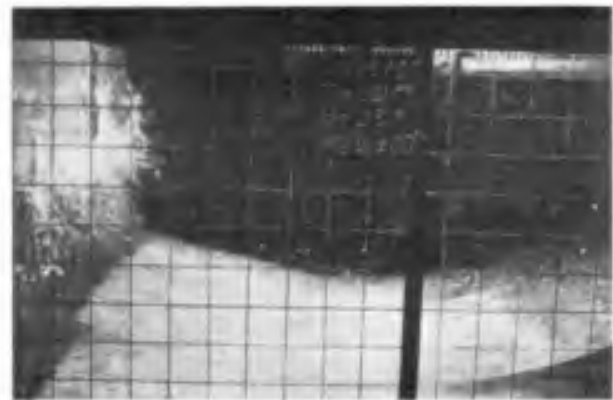

Fig. 20.

Figs. $15-20$. Behavior of the wave in front of the steel-pipe breakwater with a rubble mound. 


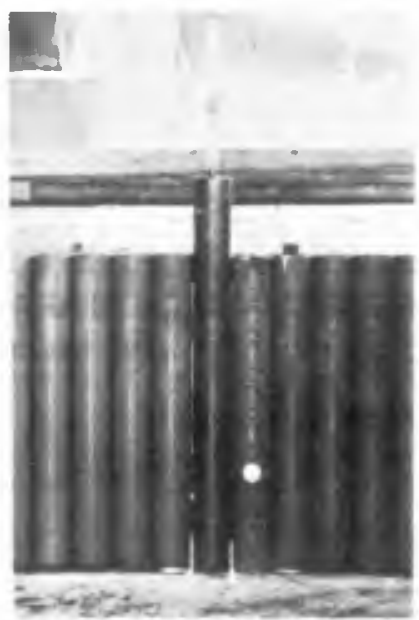

Fig. 21.

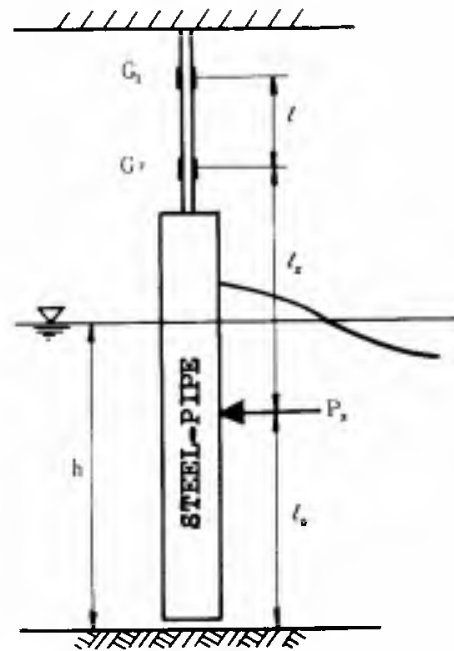

Fig. 22.

Figs. $21-22$. Measurement of resultant pressure on one steel pipe by the moment method.

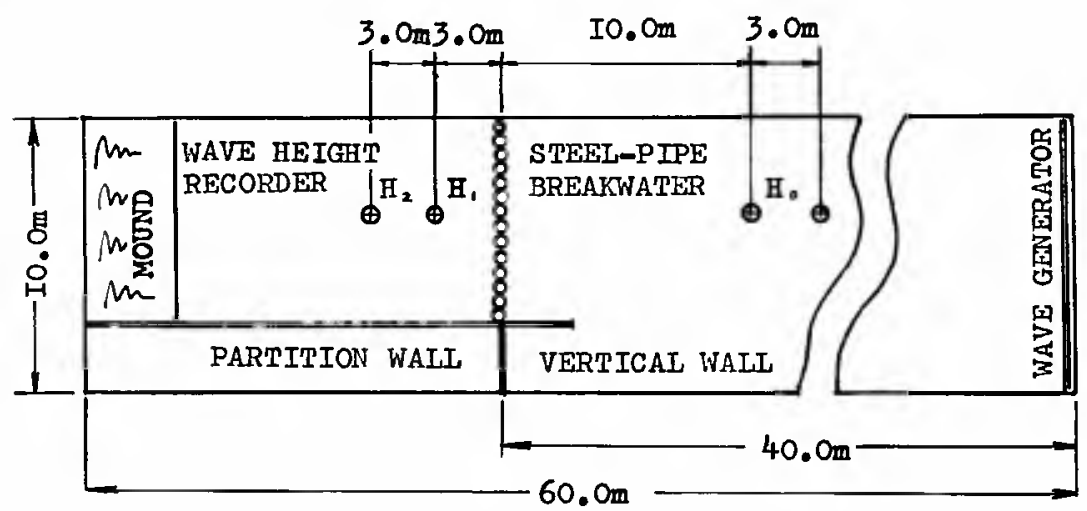

Fig. 23. Schematic layout of the experimental equipments in the wave tank.

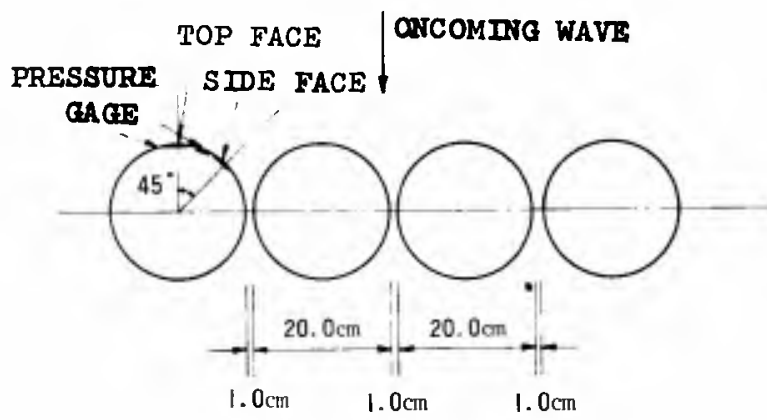

Fig. 24. Plan of the steel pipe breakwater. 


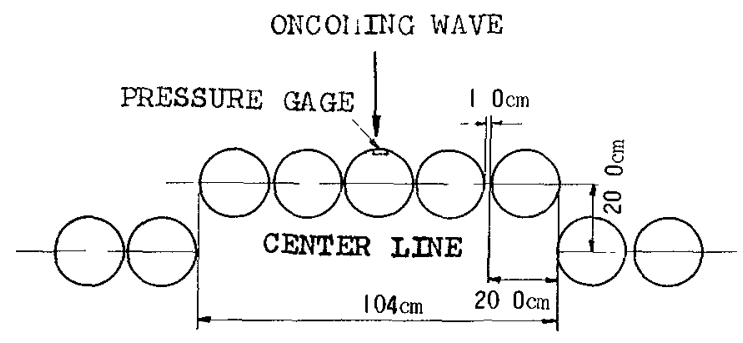

Fig. 25. Plan of the steel pipe breakwater reconstructed after destruction.

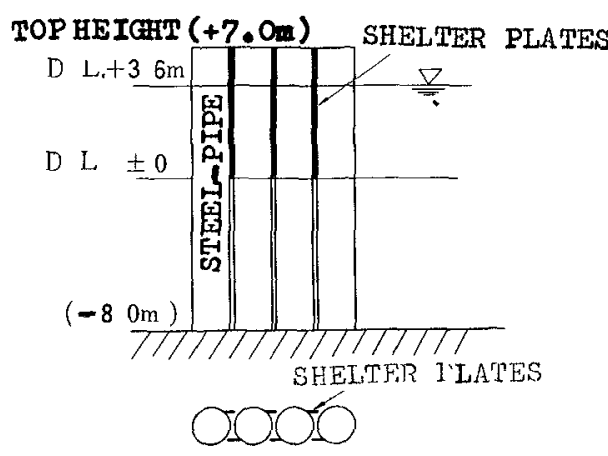

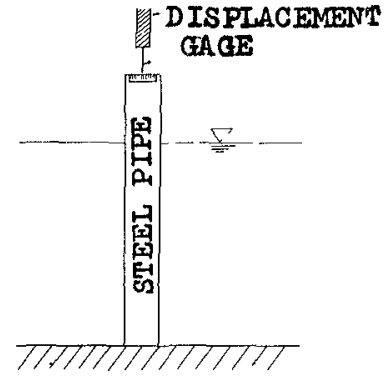

Fig. 26.

Measurement of deflections at the top of the pipe.

Fig. 27.

Iron plates welded to the pipes from L. W. L. to the top of the pipe.

\section{( Series A, Runs No. 1 and 6 )}

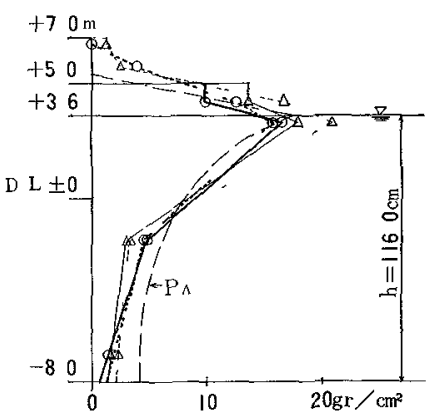

$0:$ Pressure-intensity on the top of the pipe.

$\Delta$ : Pressure-intensity on the side of the pipe. Full line: Data in the top of D.L. + 5.0m. Dotted line: Data in the top of D.L. + 7.0m.

$$
\begin{aligned}
& T_{m}=158 \mathrm{sec}-\bigcirc-\quad P_{m}=1,001 \mathrm{gr} / \mathrm{cm} \\
& H_{m}=177 \mathrm{~cm} \quad-\Delta-P_{m}=1,126 \mathrm{gr} / \mathrm{cm} \\
& L_{m}=346 \mathrm{~m} \quad \bigcirc \quad P_{m}=942 \mathrm{gr} / \mathrm{cm} \\
& H / L=0051 \quad \triangle \quad P_{m}=929 \mathrm{gr} / \mathrm{cm} \\
& h / L=0036 \quad-\ldots \ldots\left\{\begin{array}{l}
P_{17}=1,103 \mathrm{gr} / \mathrm{cm} \\
P_{A 5}=1,096 \mathrm{gr} / \mathrm{cm}
\end{array}\right.
\end{aligned}
$$

Fig. 28. Pressure distributions of the top face and the side of the steel-pipe breakwater.

\section{( Series A, Runs No. 5 and 10)}

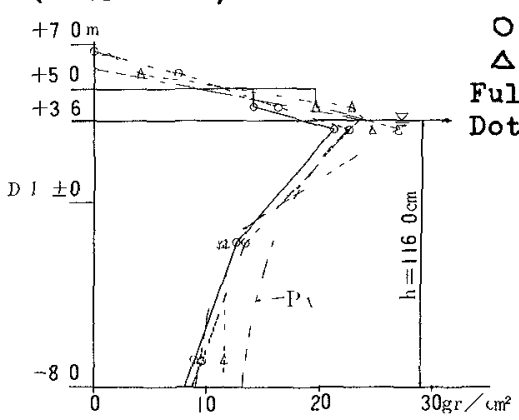

0 . Pressure-intensity on the top of the pipe.

$\Delta$ Pressure-intensity on the side of the pipe Full line: Data in the top of D.L. $+5.0 \mathrm{~m}$. Dotted line: Data in the top of D.L. + 7.0m.

$$
\begin{aligned}
& T_{m}=220 \mathrm{sec}-O-P_{m}=1,994 \mathrm{gr} / \mathrm{cm} \\
& H_{m}=236 \mathrm{~cm}-\triangle A-P_{m}=2,070 \mathrm{gr} / \mathrm{cm} \\
& L_{m}=616 \mathrm{~m} \circlearrowleft P_{m}=1,881 \mathrm{gr} / \mathrm{cm} \\
& H / L=0037 \triangle P_{m}=2,119 \mathrm{gr} / \mathrm{cm} \\
& h / L=0188 \ldots-\left\{\begin{array}{l}
P_{n t r}=2,194 \mathrm{gr} / \mathrm{cm} \\
P_{A 5}=2,150 \mathrm{gr} / \mathrm{cm}
\end{array}\right.
\end{aligned}
$$

Fig. 29. Pressure distributions of the top face and the side of the steel-pipe breakwat 
Table 5. Resultant of wave pressures on one steel pipe (Steel pipe breakwater without a rubble mound)

\begin{tabular}{c|c}
\hline $\begin{array}{c}h_{m} \\
(\mathrm{~cm})\end{array}$ & $\begin{array}{c}T_{m} \\
(\mathrm{sec})\end{array}$ \\
\hline 53.3 & 1.29 \\
$n$ & 1.31 \\
$"$ & 1.54 \\
$"$ & 1.65
\end{tabular}

\begin{tabular}{|c|c}
$\begin{array}{c}H_{\mathrm{a}} \\
(\mathrm{cm})\end{array}$ & $\begin{array}{c}L \text { s } \\
(\mathrm{cm})\end{array}$ \\
\hline 13.0 & 222 \\
16.5 & 231 \\
17.9 & 285 \\
16.2 & 302
\end{tabular}

\begin{tabular}{l|l}
$/ L$ & $h / L$ \\
\hline 0.059 & 0.241 \\
0.071 & 0.231 \\
0.063 & 0.187 \\
0.054 & 0.187
\end{tabular}

\begin{tabular}{|c|c|c|c|c|c|c|}
\hline$h / H$ & $\underset{(\mathrm{gr} / \mathrm{cm})}{P_{m A}}$ & $\begin{array}{c}P_{m} \rho O \\
(\mathrm{gr} / \mathrm{cm})\end{array}$ & $\begin{array}{l}l_{0} \\
(\mathrm{~cm})\end{array}$ & $\underset{\left(\mathrm{gr} /{ }^{\prime}\right.}{\left.P_{\text {本 }}\right)}$ & $\begin{array}{c}l_{01} \\
(\mathrm{~cm})\end{array}$ & $P_{x} / P_{m e o} \times D_{m}$ \\
\hline 4.10 & 604 & 481 & 37.1 & 5,890 & 43.0 & 1.23 \\
\hline 3.23 & 681 & 643 & 37.9 & 7,360 & 38.2 & 1.15 \\
\hline 2.98 & 832 & 835 & 37.2 & 9,400 & 41.0 & 1.13 \\
\hline 3.29 & 731 & 737 & 35.8 & 8,970 & 39.0 & 1.22 \\
\hline
\end{tabular}

$P_{x}$ : Resultant pressure exerted on one pipe calculated by the moment method.

Pmeo: Resultant pressure on the top face of the pipe.

$\mathrm{D}_{m}$ : Diameter of the pipe.

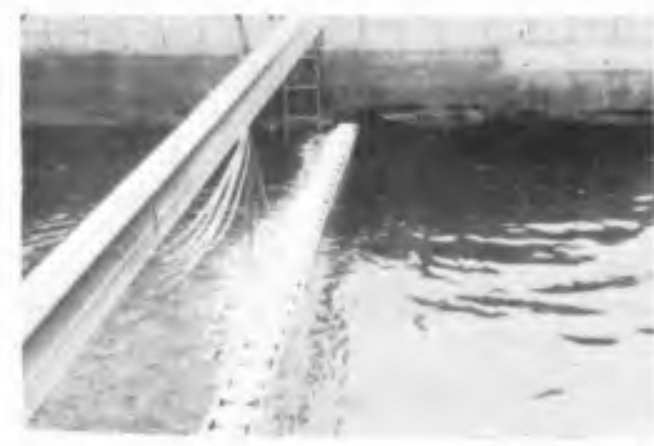

(a) Series A, Run No. 1 .

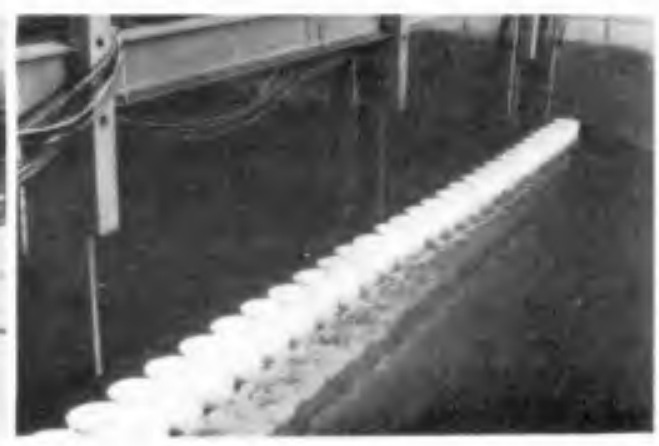

(b) Series A, Run No. 6 .

Fig. 30. Behaviors of waves around the breakwater.

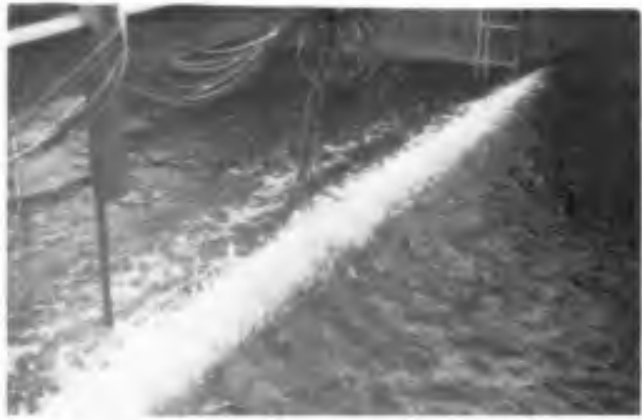

(a) Series A, Run No. 5.

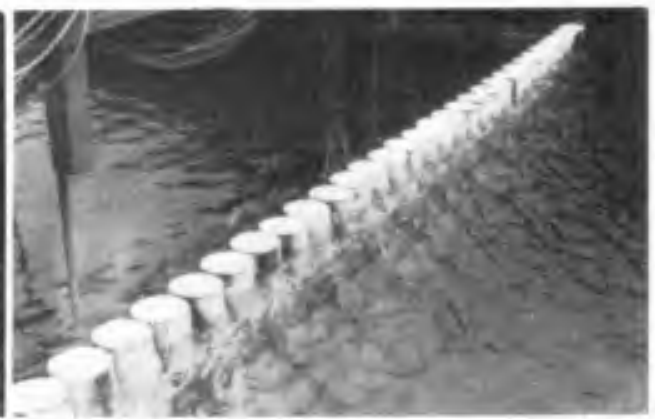

(b) Series A, Run No. 10.

Fig. 31. Behaviors of waves around the breakwater. 
( Series C, Runs No. 3 and 6 )

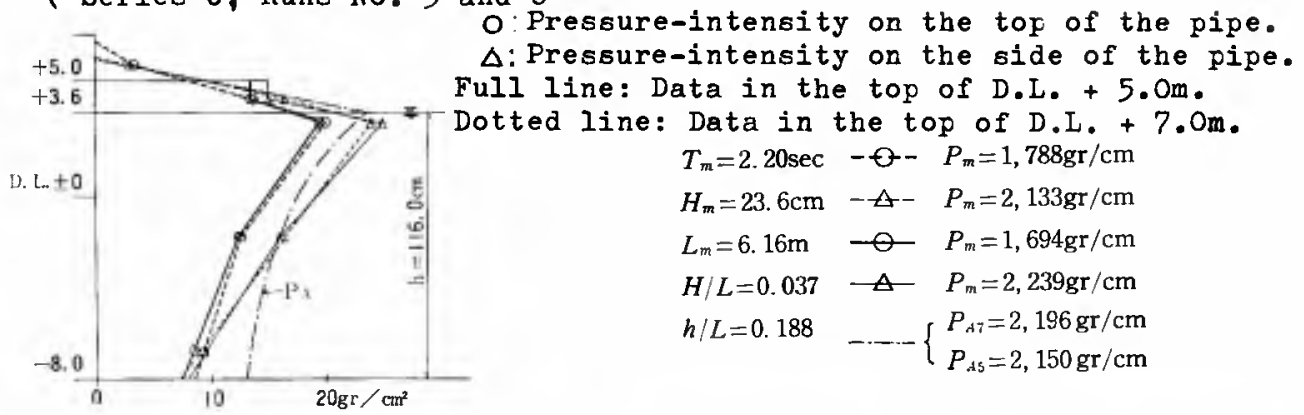

Fig. 32. Pressure distributions of the top face and the side of the steel-pipe breakwater.

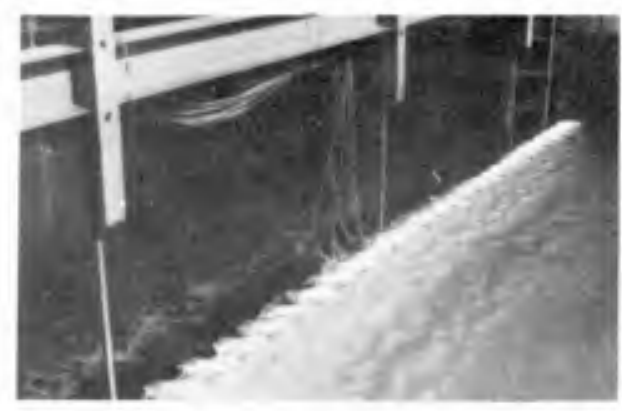

(a) Series C, Run No. 3 .

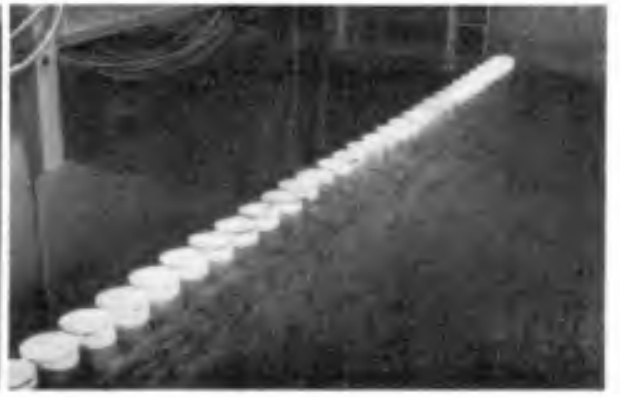

(b) Series C, Run No. 6 .

Fig. 33. Behaviors of waves around the breakwater.

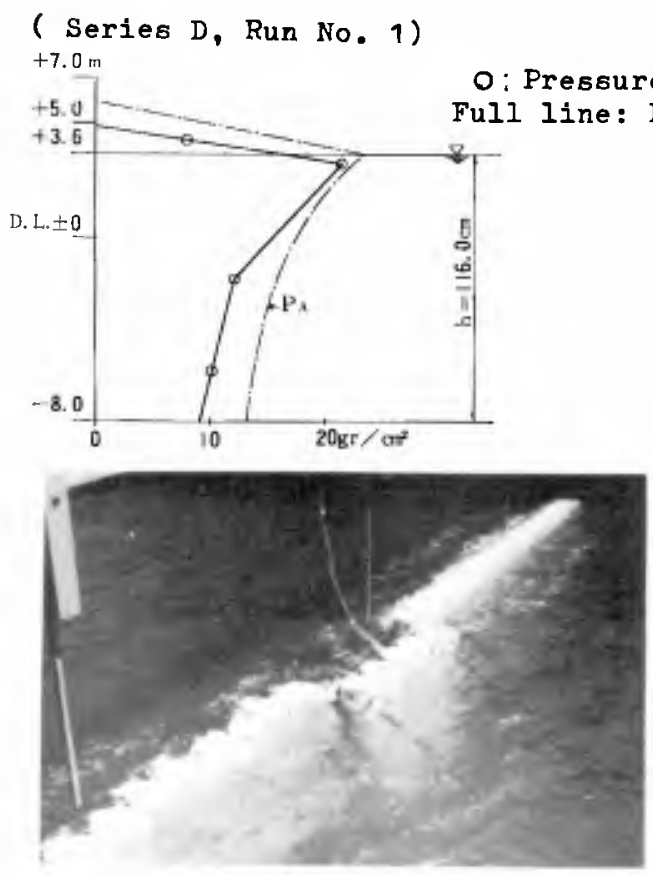

(a) Series D, Run No. 1.

Fig. 34. Experiments concerned with the reconstructed part. 


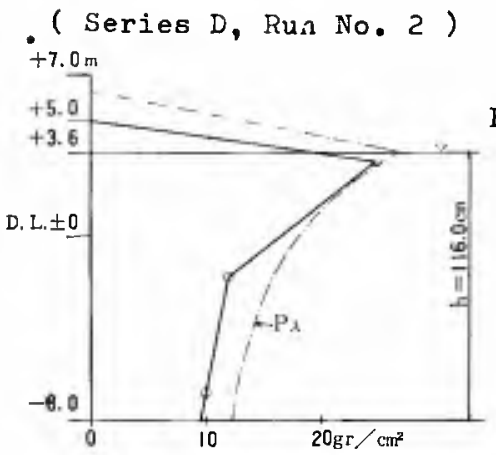

$0:$ Pressure-intensity on the top of the pipe. Full line: Data in the top of D.L. $+5.0 \mathrm{~m}$.

(a) Series D, Run No. 2

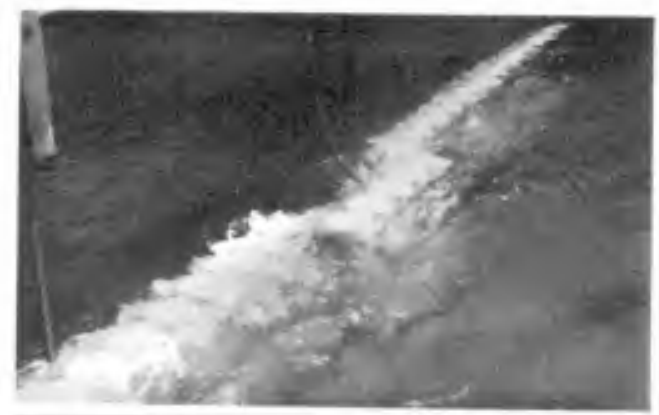

$$
\begin{aligned}
& T_{m}=1.93 \mathrm{sec} \\
& H_{m}=26: 7 \mathrm{~cm} \\
& L_{m}=5.13 \mathrm{~m} \quad-\Theta P_{m}=1,8(2) 2 \mathrm{gr} / \mathrm{cm} \\
& H / L=0.052 \\
& h / L=0.226 \quad---P_{A 5}=2,216 \mathrm{gr} / \mathrm{cm}
\end{aligned}
$$

Fig. 35. Experiments concerned with the reconstructed part.
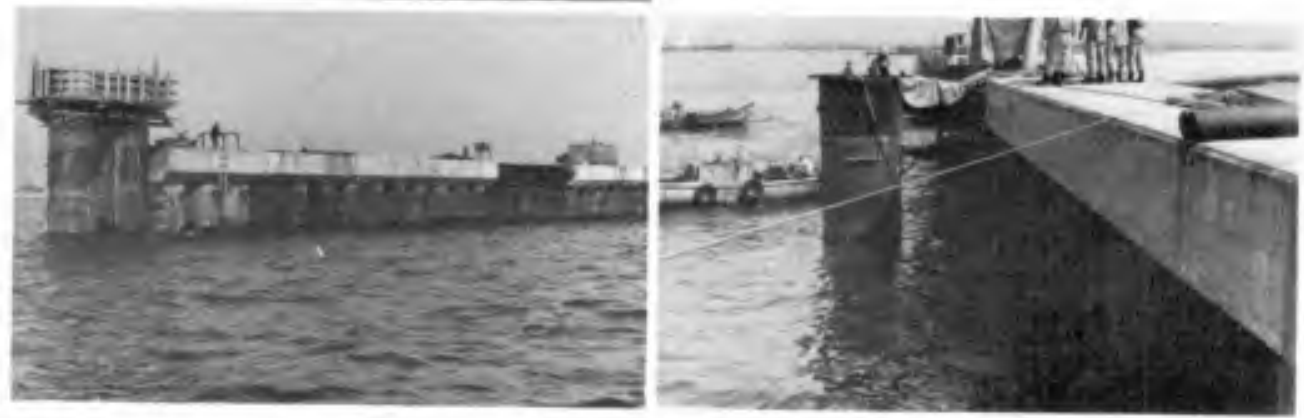

Fig. 36. Steel-pipe breakwater in near Fig. 37. Steel-pipe breakwater undercompletion in the Port of Osaka.

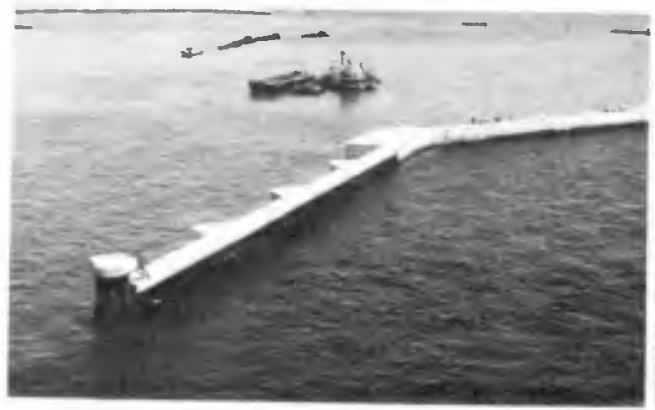

Fig. 38. Steel-pipe breakwater after completion.

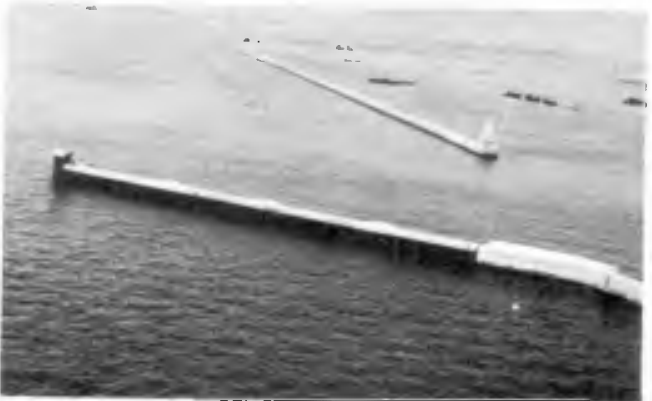

Fig. 39. Steel-pipe breakwater after completion. 

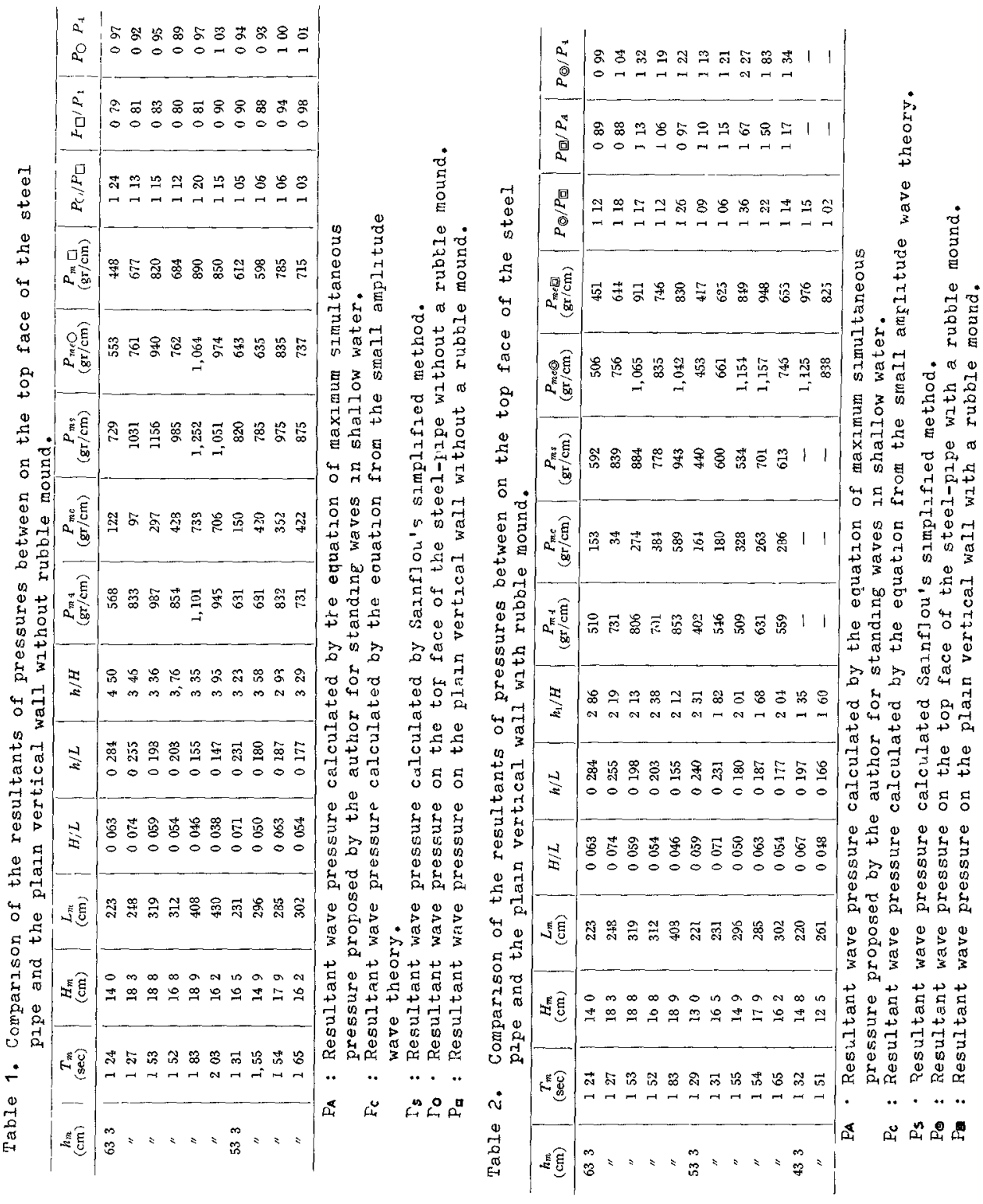

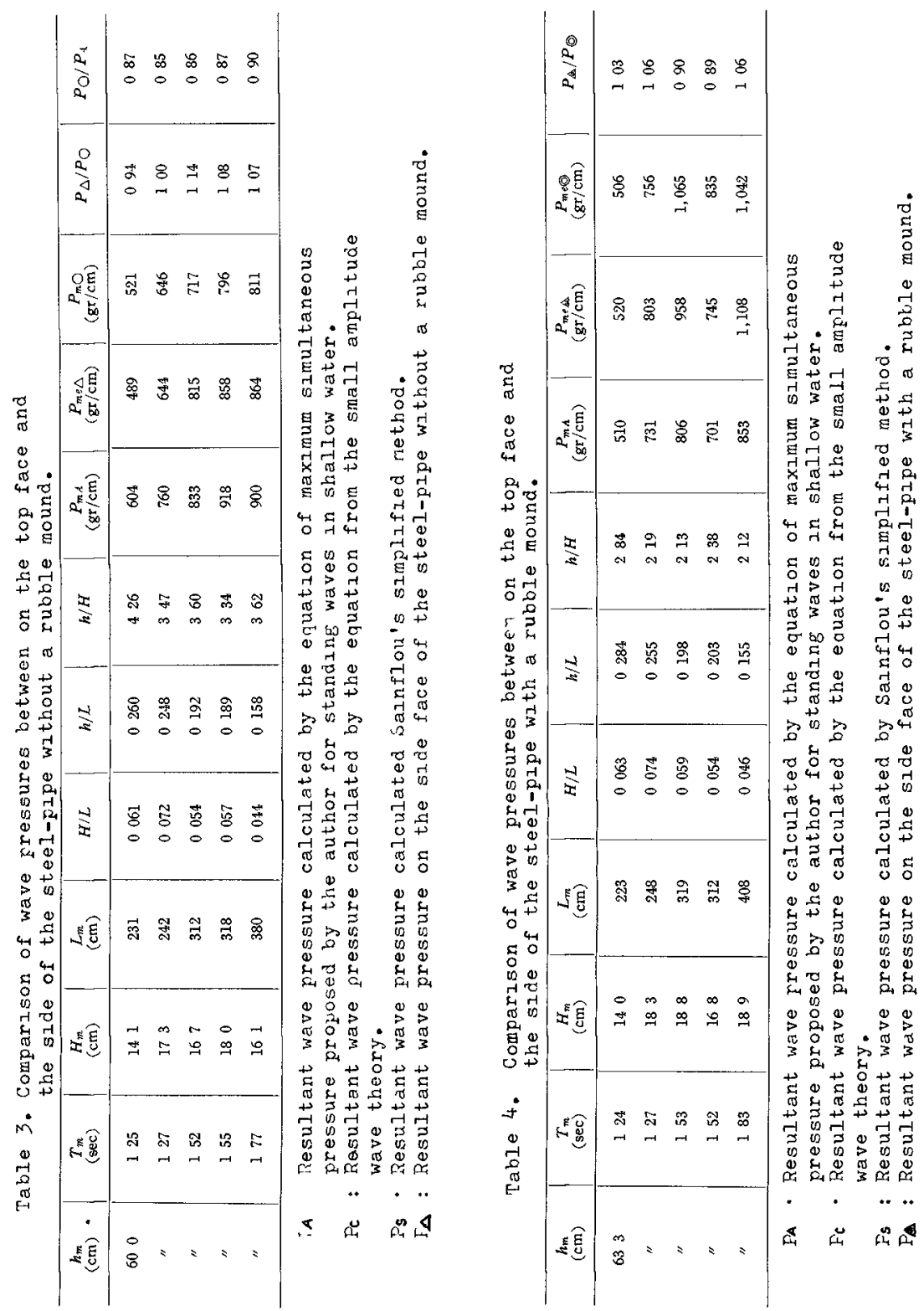


\begin{tabular}{|c|c|c|c|c|c|c|c|c|c|c|c|c|}
\hline 蛋 & 坣 & 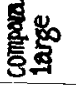 & 莺 & s & • & 范 & $=$ & $=$ & $=$ & s & $=$ & $=$ \\
\hline $\begin{array}{ll}2 & 3 \\
2 & 3 \\
4 & 3 \\
3 & 3\end{array}$ & 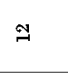 & $\dddot{m}$ & 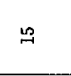 & $\stackrel{\leftrightarrow}{\sim}$ & $\stackrel{\bullet}{\sim}$ & $\Im$ & $m$ & 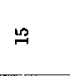 & 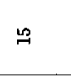 & 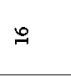 & $=$ & $\stackrel{\infty}{\prime}$ \\
\hline 㩆埾 & $\therefore$ & $\therefore$ & $\ddot{m}$ & 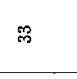 & 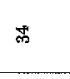 & $\stackrel{\infty}{=}$ & 9 & \pm & $\stackrel{m}{\sim}$ & $=$ & 역 & 요 \\
\hline ब行 & $\begin{array}{l}0 \\
m\end{array}$ & $\stackrel{m}{*}$ & $m$ & $\stackrel{a}{\infty}$ & $\stackrel{+}{\infty}$ & $\vec{m}$ & $\infty$ & $\vec{m}$ & $\stackrel{0}{*}$ & $\vec{r}$ & $\infty$ & $\underset{m}{m}$ \\
\hline ब & $\vec{m}$ & $\vec{\sigma}$ & $\stackrel{m}{n}$ & $\underset{\infty}{\infty}$ & $i$ & $\begin{array}{l}+1 \\
\infty\end{array}$ & $\stackrel{N}{*}$ & के & $\stackrel{\circ}{+}$ & $\begin{array}{l}a \\
\infty\end{array}$ & $\infty$ & $\stackrel{\infty}{+}$ \\
\hline$\frac{0}{2}$ & 8 & $\underset{\sim}{\stackrel{\leftrightarrow}{\prime}}$ & $\underset{-1}{\check{-}}$ & ה & $\stackrel{m}{\sim}$ & $\underset{\sim}{\stackrel{\infty}{-1}}$ & $\stackrel{2}{\rightrightarrows}$ & $\exists$ & $\Xi$ & $\underset{-}{+}$ & I & 1 \\
\hline$\frac{Q}{D}$ & $\stackrel{\infty}{\infty}$ & $\begin{array}{l}\mathscr{8} \\
0\end{array}$ & $\stackrel{8}{2}$ & $\begin{array}{l}\infty \\
: \\
0\end{array}$ & $\stackrel{\infty}{\infty}$ & $\begin{array}{l}\vec{a} \\
0\end{array}$ & $\begin{array}{r}E \\
0\end{array}$ & \& & $\begin{array}{l}5 \\
0 \\
0\end{array}$ & a & 1 & 1 \\
\hline 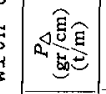 & 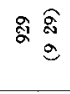 & 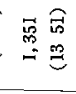 & 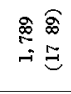 & 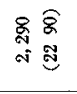 & 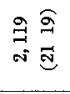 & 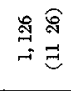 & 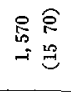 & 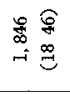 & 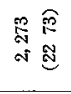 & $\begin{array}{l}\text { 옹 } \\
\text { is : }\end{array}$ & 1 & 1 \\
\hline R & 총 $\frac{\widehat{\alpha}}{0}$ & 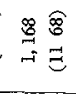 & 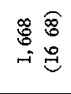 & 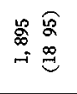 & 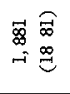 & $\begin{array}{l}\overline{8} \\
-9 \\
-9\end{array}$ & 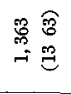 & 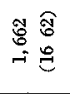 & 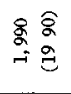 & $\begin{array}{l}\text { 善 } \\
\Rightarrow \\
=\end{array}$ & 1 & 1 \\
\hline $\mathrm{R}^{0}$ & 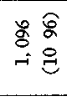 & 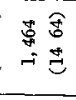 & 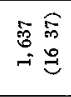 & 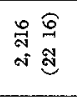 & 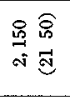 & $\begin{array}{l}\stackrel{8}{8} \stackrel{\widehat{B}}{=} \\
=E\end{array}$ & 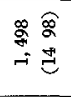 & $\stackrel{9}{\stackrel{9}{9}} \underset{\Xi}{\Xi}$ & 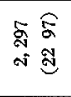 & 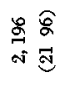 & 1 & 1 \\
\hline$\frac{1}{2}$ & $\begin{array}{l}\infty \\
\text { 号 } \\
0\end{array}$ & $\underset{\substack{\infty \\
0}}{0}$ & 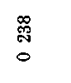 & $\begin{array}{l}\text { สี } \\
0\end{array}$ & 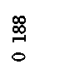 & $\begin{array}{l}\text { 品 } \\
0\end{array}$ & 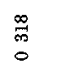 & $\begin{array}{l}\text { 㐨 } \\
0\end{array}$ & $\begin{array}{l}\text { มี้ } \\
\text { ○ }\end{array}$ & 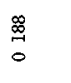 & $\begin{array}{l}\text { : } \\
\text { o }\end{array}$ & $\stackrel{\Xi}{\Xi}$ \\
\hline 这 & $\begin{array}{l}\vec{H} \\
0 \\
0\end{array}$ & $\begin{array}{l}10 \\
8 \\
0\end{array}$ & $\begin{array}{l}\text { 范 } \\
0\end{array}$ & $\begin{array}{l}\tilde{8} \\
0 \\
0\end{array}$ & $\begin{array}{l}5 \\
0 \\
0\end{array}$ & $\begin{array}{l}\text { : } \\
0 \\
0\end{array}$ & : & $\begin{array}{l}\text { 莒 } \\
0\end{array}$ & 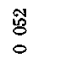 & $\begin{array}{l}\text { og } \\
0\end{array}$ & 管 & 争 \\
\hline 워희 & $\cong E$ & 洃 & 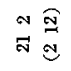 & 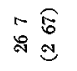 & 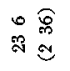 & $\begin{array}{l}\approx E \\
\Xi E\end{array}$ & 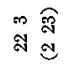 & 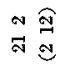 & 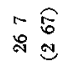 & 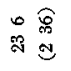 & 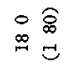 & $\begin{array}{l}0 \text { Oิ } \\
\text { N }\end{array}$ \\
\hline 고의 & 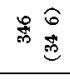 & 总命 & 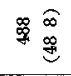 & $\stackrel{m}{\vec{m}}$ & $\begin{array}{l}0 \\
0 \\
0 \\
0 \\
0\end{array}$ & 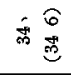 & 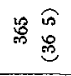 & 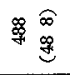 & 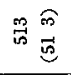 & $\begin{array}{l}0 \\
0 \\
0 \\
0\end{array}$ & 学合 & 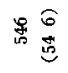 \\
\hline 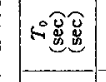 & $\begin{array}{l}\infty \\
\stackrel{8}{8} \\
\sim \\
\sim\end{array}$ & $\begin{array}{r}\infty \\
08 \\
-0 \\
-10\end{array}$ & 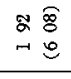 & 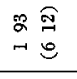 & 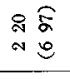 & 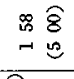 & 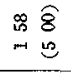 & $\begin{array}{l}\approx 0 \widehat{8} \\
-0 \\
-0\end{array}$ & $\begin{array}{l}2 \widehat{\Xi} \\
-0 \\
-0\end{array}$ & $\begin{array}{l}\text { 怘 } \\
\text { No } \\
\end{array}$ & $\begin{array}{l}\infty 0 \hat{8} \\
\sim 0 \\
\sim 0\end{array}$ & $\begin{array}{l}\circ \widehat{\phi} \\
-0 \\
-0\end{array}$ \\
\hline$=\widehat{E} \widehat{E} \widehat{E}$ & \multicolumn{10}{|c|}{ 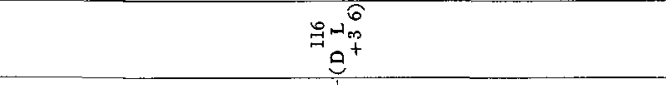 } & \multicolumn{2}{|c|}{ 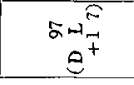 } \\
\hline$\frac{2}{2}$ & & & in & & & & & & 웅 & & & \\
\hline 急 & \multicolumn{12}{|c|}{4} \\
\hline$\stackrel{\circ}{2}$ & $r$ & N & $\infty$ & $\sigma$ & is & 0 & $r$ & $\infty$ & $a$ & 9 & & $\cong$ \\
\hline
\end{tabular}


Table $7(\mathrm{~b})$. Experimental results, movable top of the pipe with shelter plates.

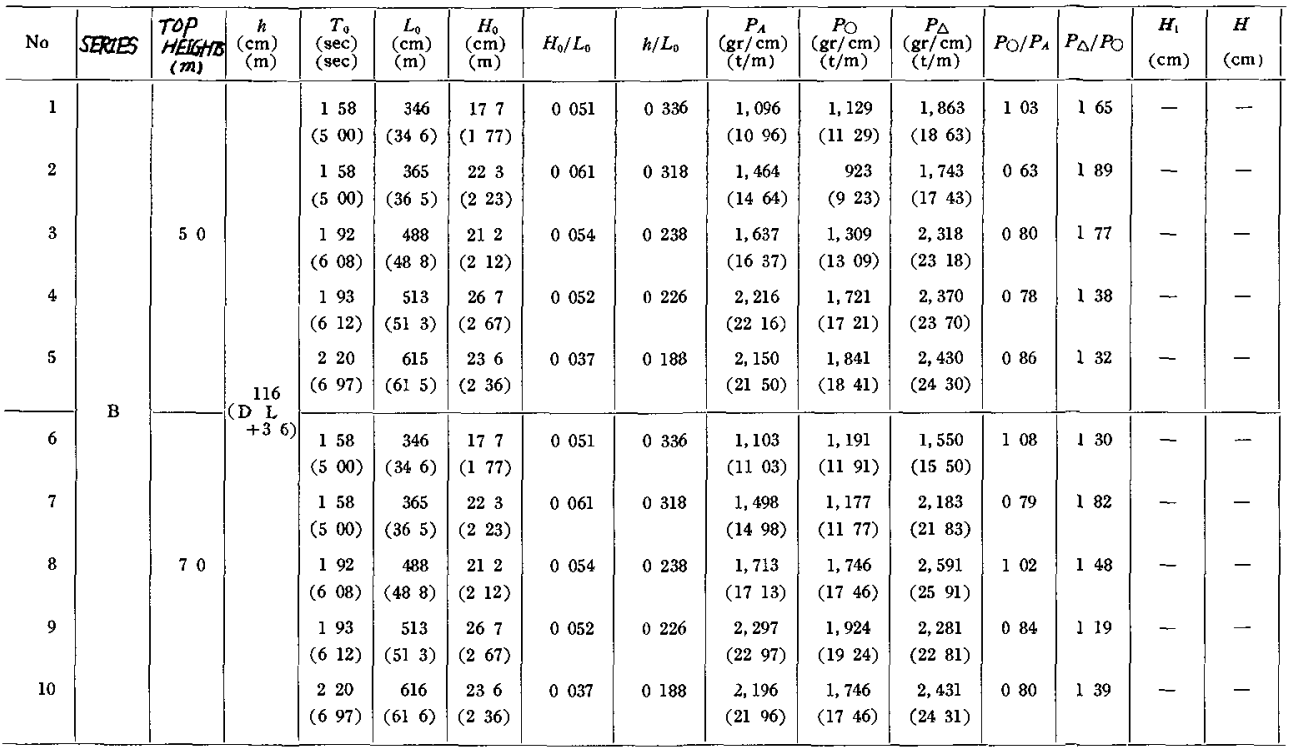

( ) Indicates the corresponding values in prototype.

Table 6. Kinds of experiments conducted.

\begin{tabular}{|c|c|c|c|c|c|c|c|}
\hline SERIES & $\begin{array}{l}\text { RATIO OF } \\
\text { SPACES } \\
\alpha(\%)\end{array}$ & $\begin{array}{c}\text { SHELTER } \\
\text { PLATES }\end{array}$ & $\begin{array}{l}\text { DIFLECT } \\
\text { OF THE TOP } \\
(C M)\end{array}$ & $\begin{array}{l}\text { WATER LEVEL } \\
\mathrm{D} \mathrm{L}+(\mathrm{m})\end{array}$ & $\begin{array}{l}\text { TOP HEIGHTS } \\
\mathrm{D} \quad \mathrm{L}+(\mathrm{m})\end{array}$ & $\begin{array}{l}\text { OBJECT } \\
\text { OF EXPER. }\end{array}$ & REFERENCE \\
\hline A & [- - & with & 0 & $\begin{array}{l}36 \\
17\end{array}$ & $\begin{array}{ll}5 & 0 \\
7 & 0 \\
7 & 0\end{array}$. & $\mid \begin{array}{l}\text { mave pressure } \\
\text { ratio of trausen } \\
\text { ratio of transon. }\end{array}$ & Table $7(\mathrm{a})$ \\
\hline $\mathrm{B}$ & 5 & with & 20 & 36 & $\begin{array}{ll}5 & 0 \\
7 & 0\end{array}$ & wave pressure & Table $7(b)$ \\
\hline $\mathrm{C}$ & 5 & without & 0 & $\begin{array}{ll}3 & 6 \\
1 & 7 \\
1 & 1\end{array}$ & $\begin{array}{ll}5 & 0 \\
7 & 0 \\
5 & 0 \\
5 & 0\end{array}$ & $\begin{array}{c}\text { wave pressure } \\
\text { ratio of transm } \\
\text { ratio of truam. } \\
\text {. }\end{array}$ & Table 7 (c) \\
\hline $\mathbf{D}$ & 5 & without & 0 & 36 & 50 & $\begin{array}{l}\text { Wha ve pressure } \\
\text { ratio of transin. }\end{array}$ & \\
\hline $\mathbf{E}$ & 5 & without & 70 & 36 & 70 & ratio of transon & \\
\hline
\end{tabular}

$\alpha$ : Ratzo of spaces between the pipes against the diameter of pipe. $\alpha=\mathrm{d} / D$ 


\begin{tabular}{|c|c|c|c|c|c|c|c|c|c|c|c|}
\hline & 莣 & 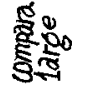 & 喿 & 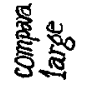 & $\underset{\vec{z}}{\vec{z}}$ & $=$ & $=$ & $=$ & $=$ & $=$ & $=$ \\
\hline & 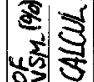 & จิ & ลี & ส & สิ & ส & สิ & ส & సิ & สี & ส \\
\hline & 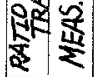 & ฟ & $\mathscr{F}$ & ร & ๓ & 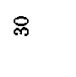 & $\mathscr{\sim}$ & ริ & $\ddot{m}$ & $\mathscr{乛}$ & $\ddot{m}$ \\
\hline & $\approx \approx$ ] & $\stackrel{a}{a}$ & $\begin{array}{l}0 \\
\Rightarrow\end{array}$ & $a$ & 0 & $\vec{\infty}$ & $\ddot{0}$ & $\vec{b}$ & $\dddot{n}$ & is & is \\
\hline 4 & 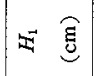 & $a$ & $\vec{H}$ & $a$ & $\begin{array}{l}1 \\
0\end{array}$ & 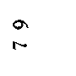 & w & $\overrightarrow{0}$ & $\stackrel{s}{n}$ & is & $\begin{array}{l}a \\
+\end{array}$ \\
\hline & $\frac{8}{4}$ & $\stackrel{\text { 岕 }}{=}$ & J & $\stackrel{\text { ळొ }}{\sim}$ & $\stackrel{\vec{J}}{-}$ & $\stackrel{\leftrightarrow 口}{\leftrightarrows}$ & $\stackrel{9}{7}$ & 1 & 1 & 1 & 1 \\
\hline & $e_{0}^{R}$ & $\begin{array}{l}\pi \\
0\end{array}$ & $\begin{array}{l}尺 \\
0\end{array}$ & $\begin{array}{l}2 \\
0\end{array}$ & $\stackrel{N}{\circ}$ & $\stackrel{\infty}{2}$ & $\begin{array}{l}\vec{\infty} \\
0\end{array}$ & I & 1 & 1 & 1 \\
\hline & 还息 & 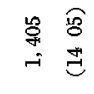 & 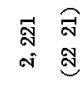 & 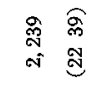 & 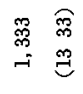 & 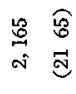 & $\begin{array}{ll}\stackrel{m}{m} & \widehat{m} \\
\sim & \vec{d}\end{array}$ & I & 1 & 1 & 1 \\
\hline & Q & 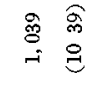 & $\begin{array}{ll}\overrightarrow{6} & 6 \\
0 & 0 \\
-0 & 0\end{array}$ & 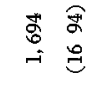 & $\begin{array}{ll}\infty & 0 \\
0 & 0 \\
-i & \varrho\end{array}$ & 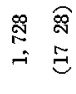 & 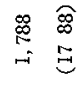 & I & 1 & 1 & 1 \\
\hline & Q & 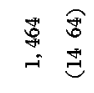 & 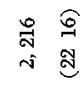 & 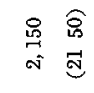 & 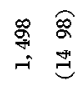 & 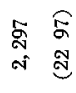 & 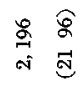 & $i$ & 1 & 1 & 1 \\
\hline & 닌 & $\begin{array}{l}\infty \\
m \\
0\end{array}$ & $\begin{array}{l}\text { สั } \\
0\end{array}$ & 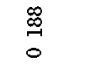 & $\begin{array}{l}\infty \\
m \\
0\end{array}$ & $\begin{array}{l}\text { สิ } \\
0\end{array}$ & $\begin{array}{l}\stackrel{\mathscr{p}}{9} \\
0\end{array}$ & $\begin{array}{l}\stackrel{ }{2} \\
\text { O }\end{array}$ & $\underset{5}{5}$ & $\begin{array}{l}\text { की } \\
\text { O }\end{array}$ & $\begin{array}{l}q \\
0 \\
0\end{array}$ \\
\hline & ì & $\begin{array}{l}\overrightarrow{8} \\
\circ\end{array}$ & $\begin{array}{l}\text { 영 } \\
0\end{array}$ & $\begin{array}{l}\text { 要 } \\
0\end{array}$ & $\begin{array}{l}\overrightarrow{8} \\
0\end{array}$ & $\begin{array}{l}\text { \% } \\
8 \\
0\end{array}$ & $\begin{array}{l}\text { 总 } \\
0\end{array}$ & $\begin{array}{l}\text { 항 } \\
0\end{array}$ & $\begin{array}{l}\text { 윻 } \\
0\end{array}$ & 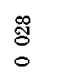 & $\begin{array}{l}\text { \% } \\
0 \\
0\end{array}$ \\
\hline & 의 $\widehat{\underline{g}}$ & 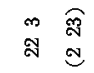 & 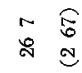 & 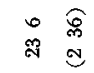 & 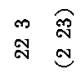 & 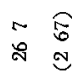 & 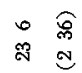 & 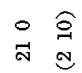 & $\begin{array}{ll}0 & \widehat{\rho} \\
\mathscr{N} \\
\tilde{N}\end{array}$ & 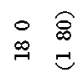 & 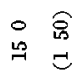 \\
\hline & 규의 & 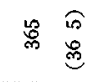 & 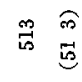 & $\begin{array}{ll}0 & 0 \\
0 & 0 \\
0\end{array}$ & 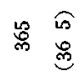 & $\begin{array}{l}\vec{m} \\
\vec{\infty} \\
\vec{b}\end{array}$ & $\begin{array}{ll}0 & 6 \\
0 & 0 \\
\vec{b}\end{array}$ & 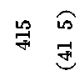 & 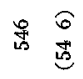 & 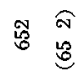 & 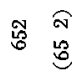 \\
\hline & 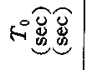 & $\begin{array}{ll}i & \hat{8} \\
\sim & b\end{array}$ & 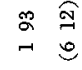 & $\begin{array}{ll}8 & \widehat{E} \\
N & 0\end{array}$ & $\begin{array}{ll}\infty & \widehat{8} \\
\rightarrow & 0\end{array}$ & 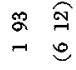 & $\begin{array}{ll}2 & \widehat{a} \\
\sim & 0\end{array}$ & 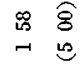 & $\begin{array}{ll}8 & \hat{8} \\
- & 0\end{array}$ & $\begin{array}{ll}\mathbb{N} & \widehat{\Xi} \\
\sim & E\end{array}$ & \begin{tabular}{ll}
\multirow{N}{*}{} & $\widehat{8}$ \\
$\sim$ & $\mathbb{C}$
\end{tabular} \\
\hline & $\approx \widehat{g} \hat{g} \widehat{g}$ & \multicolumn{6}{|c|}{$e^{\hat{6}}$} & & $e^{\tilde{A}}$ & & 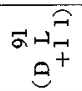 \\
\hline & م通 & & is & & & $\stackrel{0}{r}$ & & \multicolumn{4}{|c|}{ is } \\
\hline & 宸 & \multicolumn{10}{|c|}{0} \\
\hline & ஜ & $r$ & N & $m$ & + & is & 0 & $r$ & $\infty$ & $a$ & 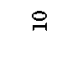 \\
\hline
\end{tabular}

